\title{
Physical and Economic Levels of Nitrogen for Aerobic Rice under Different Establishment Methods
}

\author{
K. Ramya* and R. Poonguzhalan \\ Department of Agronomy, Pandit Jawaharlal Nehru College of Agriculture \\ and Research Institute, Karaikal. 609 603, India \\ *Corresponding author
}

\section{A B S T R A C T}

\begin{tabular}{l} 
K e y w o r d s \\
Aerobic rice, \\
transplanting, line \\
sowing, \\
broadcasting, \\
nitrogen level, \\
physical and \\
economic optimum, \\
economics \\
\hline Article Info \\
\hline $\begin{array}{l}\text { Accepted: } \\
\text { 05 April } 2020 \\
\text { Available Online: } \\
\text { 10 May } 2020\end{array}$ \\
\hline
\end{tabular}

A field experiment was conducted at Pandit Jawaharlal Nehru College of Agriculture and Research Institute, Karaikal to find out the physical and economic optimum doses of nitrogen for aerobic rice under different establishment methods in Karaikal during Kharif (June to September) 2018. The treatments comprised combination of three methods of establishment (broadcasting, line sowing and transplanting) and six levels of nitrogen (0, 100, 125, 150, 175 and $200 \mathrm{~kg} \mathrm{ha}^{-1}$ ). The experiment was conducted in a split-plot design with three replications, assigning establishment methods to the main plots and the nitrogen levels to sub-plots. A short duration rice $c v$. ADT (R) 45 was used in the study. Among the different methods of establishment, the grain yield, straw yield, gross return, net return and $\mathrm{B}: \mathrm{C}$ ratio were significantly higher in transplanting than line sowing and broadcasting. Among the different nitrogen levels, the maximum grain yield, gross return, net return and $\mathrm{B}: \mathrm{C}$ ratio were recorded with the application of $150 \mathrm{~kg} \mathrm{~N} \mathrm{ha}^{-1}$. The physical and economic optimum levels of nitrogen in broadcasting (157.7 and $145.4 \mathrm{~kg} \mathrm{ha}^{-1}$, respectively), line sowing (187.2 and $170.2 \mathrm{~kg} \mathrm{ha}^{-1}$, respectively) and transplanting (157.6 and $152.0 \mathrm{~kg} \mathrm{ha}^{-1}$, respectively) varied. Transplanting rice seedlings under aerobic condition along with the application of $150 \mathrm{~kg} \mathrm{~N}^{-1}$ recorded the highest grain yield (4272 $\left.\mathrm{kg} \mathrm{ha}^{-1}\right)$, gross return (Rs. $69821 \mathrm{ha}^{-1}$ ), net return (Rs.24434 ha-1) and B:C ratio (1.54).

\section{Introduction}

'Rice is life'- a slogan in International Year of Rice 2004, had revealed the pivotal role of rice in human livelihood. But, increasing scarcity of fresh water especially for rice cultivation, due to water demand for the industries and other sectors, threatens the sustainability of the irrigated rice ecosystem.
By 2025, out of 75 million hectares, 15 million hectares of Asia's flood-irrigated rice crop will experience water shortage (Tuong and Bouman, 2003).

"Aerobic rice" concept was initiated by IRRI which means growing rice under non-puddled and non-flooded aerobic soil by the addition of external inputs like supplementary 
irrigation and fertilizers in order to overcome the ever increasing food grain demand. The aerobic way of growing rice saves water by eliminating continuous seepage and percolations, land preparation and reducing evaporation (Bouman et al., 2002). Under aerobic rice cultivation the water usage can be reduced and water productivity can be increased by 27 to 51 per cent and 32 to 88 per cent, respectively (Bouman et al., 2005).

Different establishment methods significantly influenced the yield of aerobic rice. The seedling transplanting and direct dibbling recorded more grain yield under upland condition (Laary et al., 2012). In aerobic rice, line sowing registered higher yield than broadcasting method due to maintenance of less weed population and higher weed control efficiency (Prashanthi et al., 2017). Nitrogen is the kingpin of plant nutrition and it is the most limiting nutrient for the growth and yield of rice, irrespective of the environment (Yoshida, 1981). Nitrogen application could overcome the yield decline under continuous aerobic rice cropping (Nie et al., 2008). However, the nitrogen demand of rice is not the same under different growing environments and establishment methods. Hence, the present study was undertaken with the objectives of to find out the effect of different methods of establishment and nitrogen levels on yield and economics of aerobic rice as well as to optimize the dose of nitrogen under different establishment methods.

\section{Materials and Methods}

A field experiment was conducted during kharif 2018, at east farm of Pandit Jawaharlal Nehru College of Agriculture and Research Institute, Karaikal. The soil of the experimental field was sandy clay loam in texture with a neutral $\mathrm{pH}$ (6.9). The soil was high in organic carbon (1.13\%), low in available nitrogen $\left(216 \mathrm{~kg} \mathrm{ha}^{-1}\right)$ and medium in available phosphorus (21 $\mathrm{kg} \mathrm{ha}^{-1}$ ) and available potassium (126 $\left.\mathrm{kg} \mathrm{ha}{ }^{-1}\right)$.The experiment was conducted in a split-plot design with three replications. The treatments comprised combination of three establishment methods in main plots (broadcasting, line sowing and transplanting) and six levels of nitrogen in sub-plots $(0,100,125,150,175$ and $200 \mathrm{~kg} \mathrm{ha}^{-1}$ ).

The seeds of short duration cultivar [ADT (R) 45] was used at the rate of $60 \mathrm{~kg} \mathrm{ha}^{-1}$ for the study. Under broadcasting method, the seeds were broadcasted uniformly and covered with soil. In line sowing method, rills were opened at $20 \mathrm{~cm}$ spacing, two to three seeds were sown in each hill at a spacing of $10 \mathrm{~cm}$ and the seeds were covered with soil. In transplanting method, the seeds were sown in dry flatbed nursery and later 22 days old seedlings were pulled out and transplanted in the plots according to the treatments. The nitrogen was applied as per the treatment in the form of urea in three equal splits at basal, active tillering and panicle exertion stages. Phosphorus (50 kg $\mathrm{P}_{2} \mathrm{O}_{5} \mathrm{ha}^{-1}$ ) as single super phosphate at basal and potassium $\left(50 \mathrm{~kg} \mathrm{~K}_{2} \mathrm{O}\right.$ $\mathrm{ha}^{-1}$ ) as muriate of potash in two splits (basal and panicle exertion stages) were applied uniformly to all the treatments. Immediately after sowing, the field was irrigated and life irrigation was given at 4 DAS. The plots were subsequently irrigated depending upon the soil moisture condition. Weed management and plant protection measures were taken up as per the recommendations of the Crop Production Guide.

Data on grain and straw yields were recorded. The total cost of cultivation, gross return, net return and B:C ratio were computed. The physical and economic optimum levels of nitrogen were computed using SpillmanMitscherlich yield response function (Spillman, 1923). 
$\mathrm{Y}=\mathrm{a}+\mathrm{bx}-\mathrm{cx}^{2}$

Where,

$\mathrm{Y}=$ Yield

$\mathrm{a}=$ maximum or potential yield obtainable

by not applying $\mathrm{N}$ under the conditions of the experiment

$\mathrm{b}=$ increase in yield resulting from $\mathrm{N}$ applied

$\mathrm{c}=$ ratio of successive increments in output ' $a$ ' to total output $Y$

$\mathrm{x}=\quad$ level of nitrogen

\section{Results and Discussion}

\section{Yield}

The different establishment methods significantly influenced the grain and straw yields. Transplanting rice seedlings under aerobic conditions recorded the maximum grain and straw yields (3564 and $5074 \mathrm{~kg} \mathrm{ha}^{-1}$, respectively) followed by line sowing (2716 and $4387 \mathrm{~kg} \mathrm{ha}^{-1}$, respectively). The lowest yields were recorded in broadcasting method of establishment (Table 1). The yield increase in transplanting and line sowing methods as compared to broadcasting may be attributed to the higher values of yield attributes recorded in these establishment methods as compared to those in broadcasting method.

Application of $150 \mathrm{~kg} \mathrm{~N}^{-1}$ recorded the maximum grain yield $\left(3277 \mathrm{~kg} \mathrm{ha}^{-1}\right)$ followed by $175 \mathrm{~kg} \mathrm{~N} \mathrm{ha}^{-1}\left(3164 \mathrm{~kg} \mathrm{ha}^{-1}\right), 125 \mathrm{~kg} \mathrm{~N} \mathrm{ha}^{-1}$ (3144 $\left.\mathrm{kg} \mathrm{ha}^{-1}\right)$ and $200 \mathrm{~kg} \mathrm{~N} \mathrm{ha}^{-1}(3072 \mathrm{~kg} \mathrm{ha}$ $\left.{ }^{1}\right)$. However, they were on par with each other. Whereas, application of $175 \mathrm{~kg} \mathrm{~N} \mathrm{ha}^{-1}$ recorded the maximum straw yield $(5055 \mathrm{~kg}$ $\left.\mathrm{ha}^{-1}\right)$ followed by $200 \mathrm{~kg} \mathrm{~N} \mathrm{ha}^{-1}\left(5030 \mathrm{~kg} \mathrm{ha}^{-}\right.$ $\left.{ }^{1}\right), 150 \mathrm{~kg} \mathrm{~N} \mathrm{ha}^{-1}\left(4837 \mathrm{~kg} \mathrm{ha}^{-1}\right)$ and $125 \mathrm{~kg} \mathrm{~N}$ $\mathrm{ha}^{-1}\left(4706 \mathrm{~kg} \mathrm{ha}^{-1}\right)$ which were on par with each other and significantly higher than that at $100 \mathrm{~kg} \mathrm{~N} \mathrm{ha}{ }^{-1}\left(4542 \mathrm{~kg} \mathrm{ha}^{-1}\right)$. Control recorded the lowest grain $\left(1990 \mathrm{~kg} \mathrm{ha}^{-1}\right)$ and straw yields (3393 $\mathrm{kg} \mathrm{ha}^{-1}$ ), which were significantly lower than those in all other levels of nitrogen application.

The interaction effects were significant only for grain yield. Transplanting rice seedlings along with the application of $150 \mathrm{~kg} \mathrm{~N} \mathrm{ha}^{-1}$ recorded the maximum grain yield $(4272 \mathrm{~kg}$ $\left.\mathrm{ha}^{-1}\right)$. However, it was at par with application of 125 and $175 \mathrm{~kg} \mathrm{ha}^{-1}$ in transplanting method of establishment. The least grain yield was recorded in broadcasting method of establishment with no nitrogen application $\left(1801 \mathrm{~kg} \mathrm{ha}^{-1}\right)$.

Increase in nitrogen level beyond $150 \mathrm{~kg} \mathrm{ha}^{-1}$ marginally decreased the grain yield. Similarly, a slight reduction in straw yield was noticed when the $\mathrm{N}$ was applied beyond $175 \mathrm{~kg} \mathrm{ha}{ }^{-1}$. This corroborates with the findings of Mahajan and Timsina (2011), Reddy et al., (2017) and Goswami et al., (2018). The higher yield with the application of $150 \mathrm{~kg} \mathrm{~N} \mathrm{ha}^{-1}$ was due to the increased values in the yield attributes achieved with this level of nitrogen when compared to other levels, which in turn might be due to the increased availability of nitrogen. A straw yield of $5055 \mathrm{~kg} \mathrm{ha}^{-1}$ was obtained with 175 $\mathrm{kg} \mathrm{N} \mathrm{ha}{ }^{-1}$. The increase in straw yield with increase in nitrogen might be due to higher nitrogen uptake which promoted more vegetative growth. This is in confirmation with the findings of Nayak et al., (2015).

\section{Economics}

Among the different methods of establishment, the total cost of cultivation was maximum for transplanted rice (Rs. 45,000 $\mathrm{ha}^{-1}$ ) followed by line sowing (Rs. 38,250 ha${ }^{1}$ ) while the lowest total cost of cultivation was registered in broadcasting method of establishment (Rs. 35,600 ha-1). The gross return, net return and $\mathrm{B}: \mathrm{C}$ ratio were higher in transplanting (Rs. 58,537 ha ${ }^{-1}$, Rs. 13,537 ha $^{-1}$ and 1.30 , respectively) followed by line 
sowing (Rs. 45,125 ha-1, Rs. 6,875 ha ${ }^{-1}$ and 1.18 , respectively). Broadcasting resulted in the lowest gross return, net return and B:C ratio (Table 2).

Among the various levels of nitrogen, the total cost of cultivation was higher for the application of $200 \mathrm{~kg} \mathrm{~N}^{-1}$ (Rs. 40,648 ha-1) followed by $175 \mathrm{~kg} \mathrm{~N}$ ha $^{-1}$ (Rs. 40,323 ha-1). Skipping nitrogen application resulted in the lowest total cost of cultivation (Rs. 37,681 ha $\left.{ }^{1}\right)$. Among the different nitrogen levels, the highest gross return and net return were attained with the application of $150 \mathrm{~kg} \mathrm{~N} \mathrm{ha}^{-1}$ followed by $175 \mathrm{~kg} \mathrm{~N} \mathrm{ha}^{-1}$. The lowest gross return was recorded in $\mathrm{N}$ control (Rs. 33,241 $\left.\mathrm{ha}^{-1}\right)$. A loss of Rs. $4439 \mathrm{ha}^{-1}$ was obtained when nitrogen was not applied. Application of $150 \mathrm{~kg} \mathrm{~N} \mathrm{ha}^{-1}$ recorded the highest $\mathrm{B}: \mathrm{C}$ ratio (1.34) followed by $175 \mathrm{~kg} \mathrm{~N}^{-1}$ (1.30). The lowest $\mathrm{B}: \mathrm{C}$ ratio was recorded in $\mathrm{N}$ control (0.89). Application of nitrogen beyond $150 \mathrm{~kg}$ $\mathrm{N}$ ha $^{-1}$ decreased the economic feasibility.
This is in line with the findings of Mahajan and Timsina (2011), Reddy et al., (2017) and Goswami et al., (2018).

Among the various treatment combinations, the total cost of cultivation was maximum in transplanting with application of $200 \mathrm{~kg} \mathrm{~N}$ ha ${ }^{1}$ (Rs. 46,031 ha ${ }^{-1}$ ) followed by $175 \mathrm{~kg} \mathrm{~N} \mathrm{ha}^{-1}$ in transplanting method of establishment (Rs. 45,706 $\mathrm{ha}^{-1}$ ) whereas, the total cost of cultivation was least in broadcasting with $\mathrm{N}$ control treatment (Rs. 33,664 $\mathrm{ha}^{-1}$ ). Application of $150 \mathrm{~kg} N \mathrm{ha}^{-1}$ under transplanting method resulted in the maximum gross return, net return and $\mathrm{B}: \mathrm{C}$ ratio (Rs. 69,821 ha' $\mathrm{ha}^{-1}$ Rs. 24,434 $\mathrm{ha}^{-1}$ and 1.54 , respectively) followed by application of $125 \mathrm{~kg} \mathrm{~N} \mathrm{ha}^{-1}$ under transplanting (Rs. 64,510 $\mathrm{ha}^{-1}$, Rs. 19,441 $\mathrm{ha}^{-1}$ and 1.43, respectively). Irrespective of method of establishment, a loss of Rs. 2,029 to Rs. 7,734 $\mathrm{ha}^{-1}$ was observed when nitrogen was not applied (Table 2).

Table.1 Grain and straw yields $\left(\mathrm{kg} \mathrm{ha}^{-1}\right)$ as influenced by establishment methods and nitrogen levels in aerobic rice

\begin{tabular}{|c|c|c|c|c|c|c|c|c|}
\hline \multirow[t]{2}{*}{$\mathbf{N}$-levels } & \multicolumn{4}{|c|}{ Grain yield $\left(\mathrm{kg} \mathrm{ha}^{-1}\right)$} & \multicolumn{4}{|c|}{ Straw yield $\left(\mathrm{kg} \mathrm{ha}^{-1}\right)$} \\
\hline & $\mathrm{BC}$ & LS & $\mathrm{TP}$ & Mean & $\mathrm{BC}$ & LS & $\mathrm{TP}$ & Mean \\
\hline 0 kg ha $^{-1}$ & 1801 & 2055 & 2114 & 1990 & 3093 & 3460 & 3625 & 3393 \\
\hline $100 \mathrm{~kg} \mathrm{ha}^{-1}$ & 2597 & 2609 & 3453 & 2886 & 4522 & 4205 & 4901 & 4542 \\
\hline $125 \mathrm{~kg} \mathrm{ha}^{-1}$ & 2603 & 2886 & 3943 & 3144 & 4240 & 4508 & 5370 & 4706 \\
\hline $150 \mathrm{~kg} \mathrm{ha}^{-1}$ & 2643 & 2918 & 4272 & 3277 & 4322 & 4449 & 5741 & 4837 \\
\hline $175 \mathrm{~kg} \mathrm{ha}^{-1}$ & 2659 & 2982 & 3851 & 3164 & 4810 & 4933 & 5422 & 5055 \\
\hline $200 \mathrm{~kg} \mathrm{ha}^{-1}$ & 2618 & 2845 & 3753 & 3072 & 4934 & 4770 & 5388 & 5030 \\
\hline Mean & 2487 & 2716 & 3564 & & 4320 & 4387 & 5074 & \\
\hline For & $\mathbf{E}$ & $\mathbf{N}$ & $\mathbf{N}$ at $\mathbf{E}$ & $\mathbf{E}$ at $\mathbf{N}$ & $\mathbf{E}$ & $\mathbf{N}$ & $\mathbf{N}$ at $\mathbf{E}$ & $\mathbf{E}$ at $\mathbf{N}$ \\
\hline S.Ed. & 50 & 128 & 222 & 208 & 46 & 172 & 298 & 276 \\
\hline C.D. $(P=0.05)$ & 138 & 261 & 453 & 425 & 129 & 352 & NS & NS \\
\hline
\end{tabular}

BC: Broadcasting

LS: Line sowing

TP: Transplanting 
Table.2 Economics of aerobic rice cultivation under varied establishment methods and nitrogen levels

\begin{tabular}{|c|c|c|c|c|c|c|}
\hline Treatment & $\begin{array}{l}\text { General } \\
\text { cost of } \\
\text { culti- } \\
\text { vation } \\
\left(\text { Rs. ha }^{-1}\right)\end{array}$ & $\begin{array}{l}\text { Cost of } \\
\text { establish-ment } \\
\text { and fertilizer } \\
\text { application } \\
\left(\text { Rs. ha' }{ }^{-1}\right)\end{array}$ & $\begin{array}{l}\text { Total cost } \\
\text { of culti- } \\
\text { vation } \\
\left(\text { Rs. ha }{ }^{-1}\right)\end{array}$ & $\begin{array}{c}\text { Gross } \\
\text { return } \\
\left(\text { Rs. }^{-1} \mathbf{h a}^{-1}\right)\end{array}$ & $\begin{array}{c}\text { Net } \\
\text { return } \\
\left(\text { Rs. } \text { ha }^{-1}\right)\end{array}$ & $\begin{array}{l}\mathrm{B}: \mathrm{C} \\
\text { ratio }\end{array}$ \\
\hline \multicolumn{7}{|c|}{ Establishment methods } \\
\hline $\mathbf{E}_{1}-\mathbf{B C}$ & 33264 & 2336 & 35600 & 41621 & 6021 & 1.17 \\
\hline $\mathbf{E}_{2}-\mathbf{L S}$ & 33264 & 4986 & 38250 & 45125 & 6875 & 1.18 \\
\hline $\mathbf{E}_{3}-\mathbf{T P}$ & 33264 & 11736 & 45000 & 58537 & 13537 & 1.30 \\
\hline \multicolumn{7}{|l|}{ Nitrogen levels } \\
\hline $\mathbf{N}_{0}-0 \mathbf{k g ~ N h a}^{-1}$ & 33264 & 4417 & 37681 & 33241 & -4439 & 0.89 \\
\hline $\mathrm{N}_{1}-100 \mathrm{~kg} \mathrm{~N} \mathrm{ha}^{-1}$ & 33264 & 6097 & 39361 & 47837 & 8477 & 1.21 \\
\hline $\mathrm{N}_{2}-125 \mathrm{~kg} \mathrm{~N} \mathrm{ha}^{-1}$ & 33264 & 6422 & 39686 & 51865 & 12180 & 1.30 \\
\hline $\mathrm{N}_{3}-150 \mathrm{~kg} \mathrm{~N} \mathrm{ha}^{-1}$ & 33264 & 6740 & 40004 & 53999 & 13995 & 1.34 \\
\hline $\mathrm{N}_{4}-175 \mathrm{~kg} \mathrm{~N} \mathrm{ha}^{-1}$ & 33264 & 7059 & 40323 & 52514 & 12192 & 1.30 \\
\hline $\mathrm{N}_{5}-200 \mathrm{~kg} \mathrm{~N} \mathrm{ha}{ }^{-1}$ & 33264 & 7384 & 40648 & 51108 & 10460 & 1.25 \\
\hline $\mathbf{E}_{1} \mathbf{N}_{0}$ & 33264 & 400 & 33664 & 30108 & -3556 & 0.89 \\
\hline $\mathbf{E}_{1} \mathbf{N}_{1}$ & 33264 & 2080 & 35344 & 43472 & 8128 & 1.23 \\
\hline $\mathrm{E}_{1} \mathbf{N}_{2}$ & 33264 & 2405 & 35669 & 43284 & 7615 & 1.21 \\
\hline $\mathbf{E}_{1} \mathbf{N}_{3}$ & 33264 & 2723 & 35987 & 43962 & 7975 & 1.22 \\
\hline $\mathrm{E}_{1} \mathbf{N}_{4}$ & 33264 & 3042 & 36306 & 44697 & 8391 & 1.23 \\
\hline $\mathbf{E}_{1} \mathbf{N}_{5}$ & 33264 & 3367 & 36631 & 44202 & 7571 & 1.21 \\
\hline$E_{2} \mathbf{N}_{0}$ & 33264 & 3050 & 36314 & 34285 & -2029 & 0.94 \\
\hline $\mathbf{E}_{2} \mathbf{N}_{1}$ & 33264 & 4730 & 37994 & 43345 & 5351 & 1.14 \\
\hline $\mathbf{E}_{2} \mathbf{N}_{2}$ & 33264 & 5055 & 38319 & 47803 & 9484 & 1.25 \\
\hline $\mathbf{E}_{2} \mathbf{N}_{3}$ & 33264 & 5373 & 38637 & 48214 & 9577 & 1.25 \\
\hline $\mathbf{E}_{2} \mathbf{N}_{4}$ & 33264 & 5692 & 38956 & 49663 & 10707 & 1.27 \\
\hline$E_{2} N_{5}$ & 33264 & 6017 & 39281 & 47440 & 8159 & 1.21 \\
\hline$E_{3} N_{0}$ & 33264 & 9800 & 43064 & 35330 & -7734 & 0.82 \\
\hline $\mathbf{E}_{3} \mathbf{N}_{1}$ & 33264 & 11480 & 44744 & 56696 & 11952 & 1.27 \\
\hline$E_{3} N_{2}$ & 33264 & 11805 & 45069 & 64510 & 19441 & 1.43 \\
\hline $\mathbf{E}_{3} \mathbf{N}_{3}$ & 33264 & 12123 & 45387 & 69821 & 24434 & 1.54 \\
\hline$E_{3} N_{4}$ & 33264 & 12442 & 45706 & 63183 & 17477 & 1.38 \\
\hline$E_{3} N_{5}$ & 33264 & 12767 & 46031 & 61683 & 15652 & 1.34 \\
\hline
\end{tabular}


Table.3 Physical and economic optimum levels of nitrogen for aerobic rice under different establishment methods

\begin{tabular}{|l|c|c|c|c|}
\hline $\begin{array}{l}\text { Method of } \\
\text { establishment }\end{array}$ & \multicolumn{1}{|c|}{ N- Response curve } & $\begin{array}{c}\mathbf{R}^{2} \\
\text { value }\end{array}$ & $\begin{array}{c}\text { Physical } \\
\text { optimum } \\
\mathbf{k g ~ h a}^{-1} \mathbf{)}\end{array}$ & $\begin{array}{c}\text { Economic } \\
\text { optimum } \\
\mathbf{k g ~ h a}^{-1} \mathbf{~}\end{array}$ \\
\hline Broadcasting & $\mathrm{y}=1806.5+10.941 \mathrm{~N}-0.0347 \mathrm{~N}^{2}$ & $0.994 * *$ & 157.7 & 145.4 \\
\hline Line sowing & $\mathrm{y}=2038.1+9.3978 \mathrm{~N}-0.0251 \mathrm{~N}^{2}$ & $0.952^{* *}$ & 187.2 & 170.2 \\
\hline Transplanting & $\mathrm{y}=2076.9+23.923 \mathrm{~N}-0.0759 \mathrm{~N}^{2}$ & $0.936^{* *}$ & 157.6 & 152.0 \\
\hline $\begin{array}{l}\text { Across all } \\
\text { methods }\end{array}$ & $\mathrm{y}=1973.8+14.748 \mathrm{~N}-0.0452 \mathrm{~N}^{2}$ & $0.976^{* *}$ & 163.1 & 153.7 \\
\hline
\end{tabular}
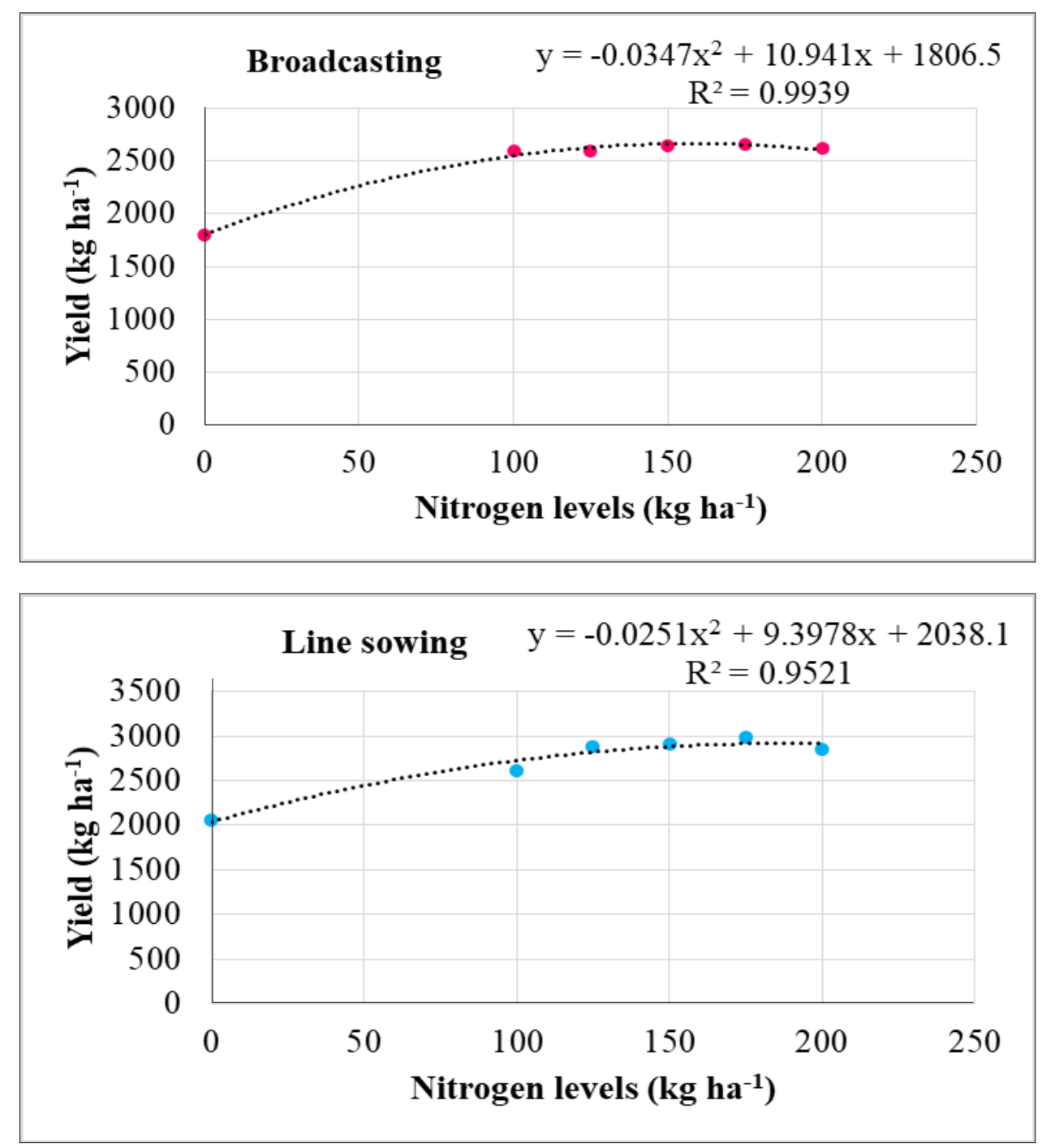


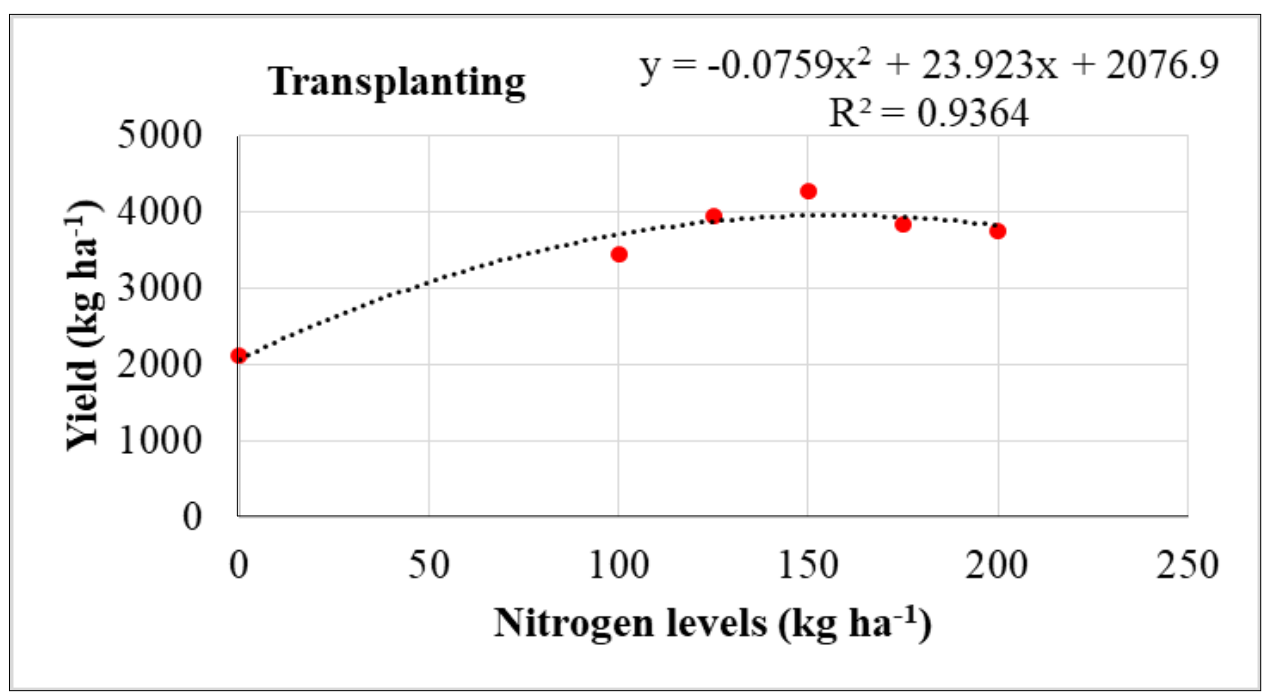

Fig.1 Response of aerobic rice to nitrogen under different establishment methods

\section{Physical and economic optimum}

The $\mathrm{N}$ response curves under different methods of establishment are presented in Fig.1. The $\mathrm{N}$ response curves adequately explain the grain yield response of aerobic rice to different nitrogen levels under varied establishment environments.

The physical and economic optimum nitrogen levels in broadcasting (157.7 and $145.4 \mathrm{~kg}$ ha 1 , respectively), line sowing (187.2 and 170.2 $\mathrm{kg} \mathrm{ha}^{-1}$, respectively) and transplanting (157.6 and $152.0 \mathrm{~kg} \mathrm{ha}^{-1}$, respectively) varied. Across the methods of establishment, the physical optimum level of nitrogen was found to be $163.1 \mathrm{~kg} \mathrm{ha}^{-1}$ whereas the economic optimum level of nitrogen was found to be $153.7 \mathrm{~kg} \mathrm{ha}^{-1}$ (Table 3).

From the above results, it is clear that rice could be transplanted under aerobic conditions to achieve better growth and yield. To achieve higher yield and economic return, it is recommended that rice can be transplanted under aerobic condition with application of $150 \mathrm{~kg} \mathrm{~N} \mathrm{ha}^{-1}$.

\section{References}

Bouman, B. A. M., Humphreys, E., Tuong, T. P. and Barker, R. 2005. Rice and water. Adv. Agron., 97: 187-237.

Bouman, B.A.M., Xiaoguang, Y., Huaqui, W., Zhiming, W., Junfang, Z., Changgui, W. and Bin, C., 2002. Aerobic rice (Han Dao): A new way of growing rice in water short areas. In: Proc. The 12th Intl. Soil Conservation Organization Conf. May 26-31, Beijing, China. Tsinghua University. pp. 175181.

Goswami, G., Singh, Y. and Kumar, S., 2018. Performance of direct seeded rice as influenced by mulching, nitrogen levels and weed management practices in eastern part of Uttar Pradesh. Int. J. Chemical Studies, 6(2): 700-703.

Laary, J. K., Dogbe, W., Boamah, P. O. and Agawini, J., 2012. Evaluation of planting methods for growth and yield of "Digang" rice (Oryza sativa L.) under upland condition of Bawku, Upper East Region, Ghana. ARPN J. Agric. Bio. Sci., 7(10): 814-819. 
Mahajan, G. and Timsina, J., 2011. Effect of nitrogen rates and weed control methods on weeds abundance and yield of direct-seeded rice. Archives Agron. Soil Sci., 57(3): 239-250.

Nayak, B. R., Pramanik, K., Panigrahy, N., Dash, A. K. and Swain, S. K., 2015. Yield, nitrogen uptake and nitrogen use efficiency indices of aerobic rice (Oryza sativa L.) under various irrigation regimes and nitrogen levels. Int. J. Biores. Env. Agril. Sci., 1(2): 8-13.

Nie, L., Peng, S., Bouman, B. A. M., Huang, J., Cui, K., Visperas, R. M. and Xiang, J., 2008. Alleviation of soil sickness caused by aerobic monocropping: Growth response of aerobic rice to nutrient supply. Field Cr. Res., 107:129-136.

Prashanthi, C.H., Laxminarayanan, P., Vidyasagar, G.E.C.H. and Harish Kumar Sharma, S., 2017. Yield parameters and yield of aerobic rice (Oryza sativa) as influenced by different seeding methods and weed control measures. Int. J. Curr. Microbio. App. Sci., 6(7): 2474-2480.

Reddy, B. G. M., Guruprasad, G. S., Paramesh, D., Mahantashivayogayya, K. and Ibrahim, M., 2017. Nitrogen management for optimum productivity of dry direct seeded rice (Oryza sativa L.) under medium deep black soils. $J$. Farm Sci., 30(2): 177-180.

Spillman, W. J., 1923. Application of the law of diminishing returns to some fertilizers and feed data. J. Farm Econ., 5: 36-52.

Tuong, T.P. and Bouman, B.A.M., 2003. Rice production in water-scarce environments. In: Water Productivity in Agriculture: Limits and opportunities for Improvement, J.W. Kijne, R. Barker, D. Molden. (Eds). CABI Publishing, UK, pp. 53-67.

Yoshida, S. 1981. Fundamentals of Rice Crop Science. Los Banos, Philippines: International Rice Research Institute.

\section{How to cite this article:}

Ramya. K and Poonguzhalan. R. 2020. Physical and Economic Levels of Nitrogen for Aerobic Rice under Different Establishment Methods. Int.J.Curr.Microbiol.App.Sci. 9(05): 985-992. doi: https://doi.org/10.20546/ijcmas.2020.905.108 